\title{
COVID-19 and Diabetes - Prevalence and Prognosis: A Single-Center Experience
}

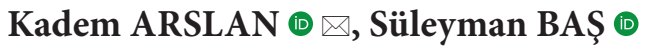 \\ Sancaktepe Sehit Prof. Dr. Ilhan Varank Training and Research Hospital, Department of Internal Medicine, Istanbul, Turkey \\ Cite this article as: Arslan K, Baş S. COVID-19 and Diabetes - Prevalence and Prognosis: A Single-Center Experience. Turk J Diab Obes 2021;2: 180-185.
}

\begin{abstract}
Aim: We aimed to investigate the prevalence of diabetes in COVID-19 patients and the effect of diabetes on the course of COVID-19 disease.

Material and Methods: Patients diagnosed with COVID-19 disease in Istanbul Sancaktepe Martyr Prof. Dr. Ilhan Varank Training and Research Hospital between 01/06/2020 and 30/10/2020 were included in the study. Medical records of patients were analyzed from the hospital information management system. We examined medical history, PCR test results, blood test results, computerised tomography reports, hospitalization and treatment results.

Results: 2414 patients, 1145 females and 1269 males were included in the study. The diabetes prevalence in the whole group was $18.6 \%$. The rate of hospitalization and the rate of admission to intensive care unit was significantly higher in diabetics than non-diabetics. In the diabetic group; total length of stay in hospital and intensive care unit was significiantly higher. The rate of presence of pneumonia on tomography was significantly higher in diabetics. The mortality rate was significiantly higher in diabetics than non-diabetics.

Conclusion: We found the prevalence of diabetes in COVID-19 patients to be $18.6 \%$. The rate of presence of pneumonia on thorax CT, the rate of hospitalization and the rate of admission to the intensive care unit were found to be significantly higher in diabetics. The mortality rate was found to be higher in COVID-19 patients with diabetes. Diabetes mellitus may lead to worse clinical outcomes in COVID-19 patients. COVID-19 may be more mortal in diabetic patients.
\end{abstract}

Keywords: COVID-19, Diabetes, Coronavirus, SARS-CoV-2, Prognosis

\section{COVID-19 ve Diyabet - Sıklık ve Prognoz: Tek Merkez Deneyimi}

ÖZ

Amaç: COVID-19 hastalarında diyabet prevalansını ve diyabetin COVID-19 hastalığının seyrine etkisini araştırmayı amaçladık.

Gereç ve Yöntemler: Çalışmaya 01/06/2020-30/10/2020 tarihleri arasında İstanbul Sancaktepe Şehit Prof.Dr. İlhan Varank Eğitim ve Araştırma Hastanesi’nde COVID-19 tanısı alan hastalar dahil edildi. Hastane bilgi yönetim sisteminden hastaların tıbbi kayıtları araştırıldı. Hastaların tıbbi geçmişleri, PCR test sonuçları, kan testi sonuçları, bilgisayarlı tomografi raporları, hastaneye yatış durumları ve tedavi sonuçları incelendi.

Bulgular: Çalışmaya 1145 kadın ve 1269 erkek olmak üzere toplam 2414 hasta dahil edildi.Tüm gruptaki diyabet prevalansı \% 18.6 saptandı. Diyabetiklerde; hastaneye yatış oranı ve yoğun bakıma yatış oranı diyabetik olmayanlara göre anlamlı olarak daha yüksekti. Diyabetik grupta, hastanede ve yoğun bakımda yatış süreleri anlamlı olarak daha yüksekti. Diyabetiklerde, tomografide pnömoni varlığı oranı anlamlı olarak daha yüksekti. Diyabetik hastalarda ölüm oranı daha yüksekti.

Sonuç: COVID-19 hastalarında, diyabet prevalansı \%18,6 bulundu. Toraks BT'de pnömoni görülme oranı, hastaneye yatış oranı ve yoğun bakıma yatış oranı diyabetiklerde anlamlı olarak yüksek bulundu. Diyabeti olan COVID-19 hastalarında ölüm oranı daha yüksek bulundu. Diyabet, COVID-19 hastalarında daha kötü klinik sonuçlara yol açabilir. COVID-19, diyabetik hastalarda daha ölümcül olabilir.

Anahtar Sözcükler: COVID-19, Diyabet, Koronavirüs, SARS-CoV-2, Prognoz

ORCID: Kadem Arslan / 0000-0002-3957-3821, Süleyman Baş / 0000-0002-5883-445X 


\section{INTRODUCTION}

Coronavirus disease 2019 (COVID-19) is a viral infectious disease caused by the coronavirus, severe acute respiratory syndrome coronavirus 2 (SARS-CoV-2) (1). It is a single-stranded, enveloped RNA virus named after its crown-like surface projections seen on electron microscopy (2). COVID-19 has similar clinical features as severe acute respiratory syndrome (SARS) and Middle East respiratory syndrome (MERS), and the viruses belong to the family Coronaviridae and of the subfamily Coronavirinae (2). They have greater similiarities in their structural and biochemical constituents. The symptoms include fever, cough, respiratory difficulty, myalgia, gastrointestinal features, and a myriad of other symptoms. COVID-19 was first reported in Wuhan, China, in December 2019 and has spread worldwide.

Since the onset of the disease, the number of deaths has been on the rise. In human cells, the main entry receptor for SARS-CoV-2 is angiotensin-converting enzyme 2 (ACE2), which is highly expressed in lung alveolar cells, cardiac myocytes, vascular endothelium and various other cell types $(3,4)$. In humans, the main route of SARS-CoV-2 transmission is through virus-bearing respiratory droplets (4). Generally, patients with COVID-19 develop symptoms at 5-7 days after infection.

Diabetes mellitus is a global health problem of serious importance in terms of prevalence and number of patients. Diabetes is also one of the leading chronic diseases in the world in terms of morbidity and mortality. Although the prevalence of diabetes varies between countries and societies, the increase in the number of patients and the incidence of the disease, and the place of diabetes-related problems in the list of causes of death are similar in many societies.

The relationship between diabetes and infection has been clinically known for a long time. Diabetes can negatively affect many systems with microvascular and macrovascular complications, as well as adversely affect the immune response, leading to infection tendency and a more severe course of infections. However, infections can also exacerbate diabetes and cause fluctuations in blood glucose in diabetic patients and negatively affect the prognosis. Some types of infections are more common in diabetics than non-diabetic population. Respiratory infections, especially influenza and pneumonia, are more common in diabetics compared to the other population and have a more severe course.

Diabetes causes a chronic inflammatory process characterized by metabolic and vascular abnormalities that can affect our response to pathogens. Poor glycemic control causes the immune response to be negatively affected against viral infection as well as potential secondary bacterial infection in the lungs. Diabetes impairs immunity against infection by causing changes in some steps of the immune response, including cytokine profile, $\mathrm{T}$ cell and macrophage activation (5). Hyperglycemia and insulin resistance increase the production of molecules that mediate tissue inflammation, as well as the synthesis of glycosylation end products and proinflammatory cytokines $(6,7)$. High levels of interleukin 6 (IL-6), tumor necrosis factor-alpha (TNF-a) and other inflammatory cytokines have been reported in the serum of diabetic patients (5). High levels of inflammatory cytokines such as IL-6 and TNF-alpha in diabetic patients and animal models suggest that diabetes significantly increases toll-like receptor-4 (TLR4) mediated IL-6 production (8). IL-6-dominant cytokine storms have been identified as one of the leading causes of death in SARS-CoV-2 induced pneumonia (9). Abnormal delayed type hypersensitivity reaction and complement activation dysfunction have also been described in patients with diabetes (10). Some studies have shown that exposure of pulmonary epithelial cells to high glucose concentrations significantly increases influenza virus infection and replication, which can increase viral replication with hyperglycemia (11). These inflammatory processes explain the underlying mechanism by which infections cause worse outcomes in patients with diabetes.

\section{MATERIALS and METHODS}

Patients who applied to Istanbul Sancaktepe Martyr Prof. Dr. Ilhan Varank Training and Research Hospital and diagnosed with COVID-19 between 01/06/2020 and 30/10/2020 were included in the study. Patients older than 18 years, not-pregnant, with positive COVID-19 pcr test results, and patients with thorax tomography on admission were included in the study. In all patients, gender, age, medical history, COVID-19 pcr test results, blood test results, thorax tomography reports, hospitalization status and treatment results were examined. Patients with positive COVID-19 pcr test and thorax CT were examined. The presence of COVID-19 related pneumonia findings on thorax $\mathrm{CT}$ of the patients was investigated. Hospitalization status, admission to intensive care unit, and length of hospital stay were examined. Presence of diabetes in the patients was investigated. The treatment results of the patients (exitus/healed) were investigated.

For this study, approval was obtained from the Istanbul Sancaktepe Martyr Prof. Dr. Ilhan Varank Training and Research Hospital Clinical Research Ethics Committee on 19/08/2020 with the decision number 2020/02. 


\section{Statistical Analysis}

Statistical analysis were performed using SPSS (Statistical Package for Social Sciences) 23.0 version (IBM Corporation, Armonk, NY, US). While evaluating the study data, the suitability of the parameters to the normal distribution was evaluated by Kolmogorov-Smirnov and Shapiro Wilks tests. Descriptive statistical methods including percentage and mean \pm standard deviation $( \pm \mathrm{SD})$ or median (interquartile range [IQR] were used to provide the basic features of the data, according to the evaluation of distribution for normality. An independent sample t-test was used to analyze quantitative data. Differences in the values of the variables between the groups were evaluated by the Mann-Whitney U test. Chi-square test was used to analyze qualitative data. A value of $\mathrm{P}<0.05$ was considered to be statistically significant.

\section{RESULTS}

A total of 2414 patients, 1145 females (48.2\%) and 1269 males $(51.8 \%)$ were included in the study. The median age of the group was 47 [IQR 34-58.25] (females: 48
[IQR 35-60], males: 46 [IQR 34-57] years. The median age of female patients was significantly higher than males $(\mathrm{p}<0.001)$ (Table 1). 866 patients $(35.9 \%)$ were treated at home and 1548 patients (64.1\%) were hospitalized. 62.3\% of males and $66.1 \%$ of females were hospitalized (Table $1,2)$. Hospitalization rate was significantly higher in females $(\mathrm{p}=0.024)$ (Table 1,2). Among the inpatients, 2212 patients (91.6\%) were admitted to the infectious diseases ward and 202 patients $(8.4 \%)$ were admitted to the intensive care unit (ICU). The rate of admission to the ICU was $15.4 \%$ in males and $10.6 \%$ in females. The rate of admission to ICU was higher in males $(\mathrm{p}=0.003)$ (Table 1,3). The median age of hospitalized patients was 54 [ IQR 42-65] years, and the median age of non-hospitalized patients was 35 [ IQR $26-44,25]$ years. The median age of hospitalized patients was significantly higher $(\mathrm{P}<0.001)$ (Table 2$)$. The median age of patients admitted to ICU was significantly higher $(\mathrm{p}<0.001)$ (Table 3). The median length of stay in hospital of the group was found to be 7 [IQR 6-10] days, and the median length of stay in ICU was 12 [IQR 10-17] days. Total length of stay in hospital was significantly higher in males $(\mathrm{p}=0.003)$.

Table 1: Comparison of groups by gender

\begin{tabular}{|c|c|c|c|c|}
\hline & & Male $(n=1269)$ & Female $(n=1145)$ & $\mathbf{p}$ \\
\hline Age (year) (Median) & & $46[34-57] \dagger$ & $48[35-60] \dagger$ & $=0,001^{\mathrm{a}}$ \\
\hline \multirow{2}{*}{ Diabetics/Non } & Diabetics $(n=450,18.6 \%)$ & $202(44.9 \%)$ & $248(55.1 \%)$ & \multirow{2}{*}{$<0.001^{\mathrm{b}}$} \\
\hline & Non diabetics $(\mathrm{n}=1964,81.6 \%)$ & $1067(54.3 \%)$ & $897(45.7 \%)$ & \\
\hline \multirow{2}{*}{ Hospitalization } & Non-hospitalized $(\mathrm{n}=866,35.9 \%)$ & $478(55.2 \%)$ & $388(44.8 \%)$ & \multirow{2}{*}{$=0.053^{\mathrm{b}}$} \\
\hline & Hospitalized $(\mathrm{n}=1548,64.1 \%)$ & $791(51.1 \%)$ & $757(48.9 \%)$ & \\
\hline \multirow{2}{*}{ Pneumonia on Thorax CT } & Yes $(n=1451,60.1 \%)$ & $757(52.2 \%)$ & $694(47.8 \%)$ & \multirow{2}{*}{$=0.631^{\mathrm{b}}$} \\
\hline & No $(n=963,39.9 \%)$ & $512(53.2 \%)$ & $451(46.8 \%)$ & \\
\hline \multirow{2}{*}{ Hospitalization Unit } & Ward $(n=1346,87 \%)$ & $669(49.7 \%)$ & $677(50.3 \%)$ & \multirow{2}{*}{$=0.005^{b}$} \\
\hline & ICU $(n=202,13 \%)$ & $122(60.4 \%)$ & $80(39.6 \%)$ & \\
\hline \multirow{2}{*}{ Cliinical outcome } & Healed $(n=2300,95.3 \%)$ & $1208(52.5 \%)$ & $1092(47.5 \%)$ & \multirow{2}{*}{$=0.837^{b}$} \\
\hline & Exitus $(\mathrm{n}=114,4.7 \%)$ & $61(53.5 \%)(\mathrm{E}: 4.8 \%)$ & $53(46.5 \%)(\mathrm{K}: 4.6 \%)$ & \\
\hline Length of stay in hospital & & $7[6-11] \dagger$ & $7[6-9] \dagger$ & $=0.003^{\mathrm{a}}$ \\
\hline Length of stay in ward & & $7[6-10] \dagger$ & $7[6-8] \dagger$ & $=0.099^{\mathrm{a}}$ \\
\hline Length of stay in ICU & & $12[9-17] \dagger$ & $12[11-16] \dagger$ & $=0.511^{\mathrm{a}}$ \\
\hline
\end{tabular}

${ }^{\mathrm{a}}$ Mann-Whitney test, ${ }^{\mathrm{b}}$ Chi-Square Test, $\uparrow$ Data are presented as median (interquartile range [IQR])

Table 2: Comparison by hospitalization status

\begin{tabular}{|c|c|c|c|c|c|}
\hline \multirow{2}{*}{\multicolumn{2}{|c|}{ Age (vear) (Median) }} & All Patients $(n=2414)$ & Non-hospitalized $(n=866)$ & Hospitalized $(n=1548)$ & $\mathbf{p}$ \\
\hline & an) & $47[34-58.25] \dagger$ & $35[26-44.25] \dagger$ & $54[42-65] \dagger$ & $<0.001^{\mathrm{a}}$ \\
\hline \multirow{2}{*}{ Gender } & Male & $1269(52.6 \%)$ & $478(37.7 \%)$ & $791(62.3 \%)$ & \multirow{2}{*}{$=0.053^{\mathrm{b}}$} \\
\hline & Female & $1145(47.4 \%)$ & $388(33.9 \%)$ & $757(66.1 \%)$ & \\
\hline \multirow{2}{*}{ Diabetics/Non } & Diabetics & $450(18.6 \%)$ & $46(10.2 \%)$ & $404(89.8 \%)$ & \multirow{2}{*}{$<0.001^{b}$} \\
\hline & Non-diabetics & $1964(81.6 \%)$ & $820(41.8 \%)$ & $1144(58.2 \%)$ & \\
\hline
\end{tabular}

${ }^{\mathrm{a}}$ Mann-Whitney test, ${ }^{\mathrm{b}} \mathrm{Chi}$-Square Test, $\uparrow$ Data are presented as median (interquartile range [IQR]) 
There was no significant difference in ICU length of stay to the gender. Computerised thorax tomography (Thorax CT) of the patients showed signs of COVID-19 related pneumonia in 1451 (60.1\%) patients, $963(39.9 \%)$ patients had no signs of pneumonia on thorax CT. 53.2\% of males and $46.8 \%$ of females had pneumonia on thorax CT. According to the presence of pneumonia on thorax CT, there was no significant difference to the gender (Table 1). Mortality rate in the whole group was $4.7 \%$. Mortality rate was $4.8 \%$ in males and $4.6 \%$ in females, there was no significant difference (Table 1).

There were 450 diabetic patients, all diabetics had type 2 diabetes mellitus. $55.1 \%$ of diabetic patients were females. The rate of diabetes was significantly higher in females $(\mathrm{p}<0.001)$ (Table 1,4). The diabetes prevalence in the whole group was $18.6 \%$. The median age of diabetic patients was found to be 59 [IQR 51-68] years. The median age of diabetic patients was significantly higher than non-diabeticss $(\mathrm{p}<0.001)$ (Table 4$) .89 .8 \%$ of diabetic patients were hospitalized. The rate of hospitalization was sigificantly higher in diabetic patients than non-diabetics $(\mathrm{p}<0.001)($ Table 2,4$)$. The rate of admission to ICU in diabetics was $21.1 \%$. The rate of admission to ICU was significantly higher in diabetics than non-diabetics $(\mathrm{p}<0.001)($ Table 3$)$. In the diabetic group, the median length of stay in hospital was found to be 7 [IQR 6-12] days, and the median length of stay in ICU was 12 [IQR 11 -17] days. In the diabetic group, length of stay in hospital and in ICU was significiantly higher $(\mathrm{P}<0.001$, $\mathrm{P}=0.027$ ) (Table 4). $78.4 \%$ of diabetic patients had pneumonia on thorax CT. The rate of presence of pneumonia on chest CT was significantly higher in diabetics $(\mathrm{p}<0.001)$. (Table 4) The mortality rate in diabetics was $13.3 \%$. The mortality rate was significiantly higher in diabetics than non-diabetics (Table 4).

\section{DISCUSSION}

In our study, we found the diabetes prevalence in whole group as $18.6 \%$. In a wide-ranging study conducted in Turkey in 2010, diabetes prevalence was found in $13.7 \%$, and was determined to continue to increase rapidly (12). In

Table 3: Comparison by intensive care unit admission status

\begin{tabular}{|c|c|c|c|c|c|}
\hline & & Hospitalized $(\mathbf{n}=\mathbf{1 4 5 9})$ & In Ward $(\mathrm{n}=1346)$ & In ICU $(n=202)$ & $\mathbf{p}$ \\
\hline \multicolumn{2}{|c|}{ Age (year) (Median) } & $54[42-65] \dagger$ & $52[41-61] \dagger$ & $69[56-78] \dagger$ & $<0.001^{a}$ \\
\hline \multirow{2}{*}{ Gender } & Male & $791(51.1 \%)$ & $669(84.6 \%)$ & $122(15.4 \%)$ & \multirow{2}{*}{$=0.005^{b}$} \\
\hline & Female & $757(48.9 \%)$ & $677(89.4 \%)$ & $80(10.6 \%)$ & \\
\hline \multirow{2}{*}{ Diabetics/Non } & Diabetics & $404(26.1 \%)$ & $309(76.5 \%)$ & $95(23.5 \%)$ & \multirow{2}{*}{$<0.001^{\mathrm{b}}$} \\
\hline & Non-diabetics & $1144(73.9 \%)$ & $1037(90.6 \%)$ & $107(9.4 \%)$ & \\
\hline
\end{tabular}

${ }^{\mathrm{a}}$ Mann-Whitney test, ${ }^{\mathrm{b}} \mathrm{Chi}-$ Square Test, $\dagger$ Data are presented as median (interquartile range [IQR])

Table 4: Comparison of diabetics and non-diabetics

\begin{tabular}{|c|c|c|c|c|c|}
\hline \multirow{2}{*}{\multicolumn{2}{|c|}{ Age (Year) (Median) }} & All Patients $(n=2414)$ & Diabetics $(n=450)$ & Non-diabetics $(n=1964)$ & $\mathbf{p}$ \\
\hline & & $47[34-58.25] \dagger$ & $59[51-68] \dagger$ & $43[32-55] \dagger$ & $<0.001^{a}$ \\
\hline \multirow{2}{*}{ Gender } & Male & $1269(52.6 \%)$ & $202(15.9 \%)$ & $1067(84.1 \%)$ & \multirow{2}{*}{$<0.001^{b}$} \\
\hline & Female & $1145(47.4 \%)$ & $248(21.7 \%)$ & $897(78.3 \%)$ & \\
\hline \multirow{2}{*}{ Hospitalization } & Non-hospitalized & $866(35.9 \%)$ & $46(5.3 \%)$ & $820(94.7 \%)$ & \multirow{2}{*}{$<0.001^{b}$} \\
\hline & Hospitalized & $1548(64.1 \%)$ & $404(26.1 \%)$ & $1144(73.9 \%)$ & \\
\hline \multirow{2}{*}{$\begin{array}{l}\text { Pneumonia on } \\
\text { Thorax CT }\end{array}$} & Yes & $1451(60.1 \%)$ & $353(24.3 \%)$ & $1098(75.7 \%)$ & \multirow{2}{*}{$-<0.001^{b}$} \\
\hline & No & $963(39.9 \%)$ & $97(10.1 \%)$ & $866(89.9 \%)$ & \\
\hline \multirow{2}{*}{$\begin{array}{l}\text { Hospitalization } \\
\text { Unit }\end{array}$} & Ward & $1346(87 \%)$ & $355(16 \%)$ & $1857(84 \%)$ & \multirow{2}{*}{$<0.001^{\mathrm{b}}$} \\
\hline & ICU & $202(13 \%)$ & $95(47 \%)$ & $107(53 \%)$ & \\
\hline \multirow{2}{*}{ Clinical outcome } & Healed & $2300(95.3 \%)$ & $390(17 \%)$ & $1910(83 \%)$ & \multirow{2}{*}{$-<0.001^{\mathrm{b}}$} \\
\hline & Exitus & $114(4.7 \%)$ & $60(52.6 \%)$ & $54(47.4 \%)$ & \\
\hline \multicolumn{2}{|c|}{ Length of stay in hospital } & $7[6-10] \dagger$ & $7[6-12] \dagger$ & $7[6-9] \dagger$ & $<0.001^{\mathrm{a}}$ \\
\hline \multicolumn{2}{|c|}{ Length of stay in ward } & $7[6-9] \dagger$ & $7[6-10] \dagger$ & $7[6-9] \dagger$ & $=\underset{\mathrm{a}}{=0.001}$ \\
\hline \multicolumn{2}{|c|}{ Length of stay in ICU } & $12[10-17] \dagger$ & $12[11-17] \dagger$ & $12[7-16.25] \dagger$ & $=0.027^{\mathrm{a}}$ \\
\hline
\end{tabular}

${ }^{\mathrm{a}}$ Mann-Whitney test, ${ }^{\mathrm{b}} \mathrm{Chi}$-Square Test, $\uparrow$ Data are presented as median (interquartile range [IQR]) 
the study of Guan et al. in China, the diabetes prevalence was found $16.2 \%$ in COVID-19 patients (13). In another study in China, Zhang et al found the prevalence of diabetes in COVID-19 patients $12 \%$ (14). This coincides with the results we have achieved. But, more comprehensive epidemiological studies are needed on this subject.

The rate of hospitalization and the rate of admission to intensive care unit was significantly higher in diabetics than non-diabetics.In the diabetic group; total length of stay in hospital and intensive care unit was significiantly higher. The rate of presence of pneumonia on tomography was significantly higher in diabetics. The mortality rate was significiantly higher in diabetics than non-diabetics. Also, some studies have found similar results (15). Because of the pathophysiological processes we have mentioned, we think that diabetes poses risks for COVID-19 disease. We also think that patients with non regulated diabetes will have worse results. As the comorbid diseases accompanying COVID-19 increase, the prognosis of the disease may be adversely affected. Diabetic complications, such as chronic kidney disease and ischemic heart disease, which frequently accompany diabetic patients, can further complicate the condition of people with diabetes and further increase the severity of COVID-19 disease. In addition, many patients with Type 2 diabetes can experience obesity, and obesity is a risk factor for serious infection (16). Organ dysfunction and coagulopathy and coagulation disorders can be seen in COVID-19 patients, which can result in higher mortality. Similarly, it is obvious that organ dysfunction and vascular damage can be seen in diabetes. In addition to the pronounced inflammatory process in diabetics, imbalance occurs with increased levels of coagulation factors and relative inhibition of the fibrinolytic system. It is associated with both insulin resistance and diabetes, endothelial dysfunction, and increased platelet aggregation and activation. These abnormalities support the tendency to clot in diabetes (17).

Limitations of the Study: As COVID-19 patients were followed up by specialist doctors from different branches under pandemic conditions, the HBA1C values and diabetes medications of all patients could not be reached. Therefore, comparisons could not be made according to $\mathrm{HbA1C}$ levels and diabetes medications.

\section{CONCLUSION}

We found the prevalence of diabetes in COVID-19 patients to be $18.6 \%$ in our study. In our study; the rate of presence of pneumonia on thorax CT, the rate of hospitalization and the rate of admission to the intensive care unit were found to be significantly higher in diabetics. The length of stay in hospital and intensive care unit was significantly higher in diabetics. In COVID-19 patients, the presence of diabetes can lead to worse clinical consequences. We found the mortality rate to be significantly higher in diabetics than non-diabetics. Mortality may be higher in COVID-19 patients with diabetes. COVID-19 patients with diabetes should be followed closely and monitored carefully.

Acknowledgements

None.

Author Contributions

Study concept/Design: Kadem Arslan, Data Collection: Kadem Arslan, Süleyman Baş, Data Analysis and Interpretation: Kadem Arslan, Süleyman Baş, Post draft: Kadem Arslan, Critical review of the content: Kadem Arslan, Final approval and responsibility: Kadem Arslan, Süleyman Baş, Supervision: Kadem Arslan, Süleyman Baş.

Conflict of Interest

The authors have no conflicts of interest to declare.

Financial Disclosure

There is no financial support to declare.

Ethical Approval

For this study, approval was obtained from the Istanbul Sancaktepe Martyr Prof. Dr. Ilhan Varank Training and Research Hospital Clinical Research Ethics Committee on 19/08/2020 with the decision number 2020/02.

Peer Review Process

Extremely peer-reviewed.

\section{REFERENCES}

1. Rothan HA, Byrareddy SN. The epidemiology and pathogenesis of coronavirus disease (COVID-19) outbreak. J Autoimmun. 2020;109:102433.

2. Poutanen SM. Etiologic agents of infectious diseases. In: Long SS, editor. Principles and practice of paediatric infectious diseases. 4th ed. 2012. p. 1547-712.

3. Zhang $\mathrm{H}$, Penninger JM, Li Y, Zhong N, Slutsky AS. Angiotensin-converting enzyme 2 (ACE2) as a SARS-CoV-2 receptor: Molecular mechanisms and potential therapeutic target. Intensive Care Med. 2020;46(4):586-590.

4. Huang C, Wang Y, Li X, Ren L, Zhao J, Hu Y, Zhang L, Fan G, Xu J, Gu X, Cheng Z, Yu T, Xia J, Wei Y, Wu W, Xie X, Yin W, Li H, Liu M, Xiao Y, Gao H, Guo L, Xie J, Wang G, Jiang R, Gao Z, Jin Q, Wang J, Cao B. Clinical features of patients infected with 2019 novel coronavirus in Wuhan, China. Lancet. 2020;395(10223):497-506.

5. Knapp S. Diabetes and infection: Is there a link?- A mini review. Gerontology. 2013;59:99-104. 
6. Fadaei R, Bagheri N, Heidarian E, Nouri A, Hesari Z, Moradi N, Ahmadi A, Ahmadi R. Serum levels of IL-32 in patients with type 2 diabetes mellitus and its relationship with TNF- $\alpha$ and IL-6. Cytokine. 2020;125:154832.

7. Kutlutürk F. COVID-19 pandemisi ve diabetes mellitus. Türk Diyab Obez. 2020;2:130-137.

8. Nielsen TB, Pantapalangkoor P, Yan J, Luna BM, Dekitani K, Bruhn K, Tan B, Junus J, Bonomo RA, Schmidt AM, Everson M, Duncanson F, Doherty TM, Lin L, Spellberg B. Diabetes exacerbates infection via hyperinflammation by signaling through TLR4 and RAGE. mBio. 2017;8(4):e00818-17.

9. Totura AL, Whitmore A, Agnihothram S, Schäfer A, Katze MG, Heise MT, Baric RS. Toll-like receptor 3 signaling via TRIF contributes to a protective innate immune response to severe acute respiratory syndrome coronavirus infection. mBio. 2015;6(3):e00638-15.

10. Geerlings SE, Hoepelman AI. Immune dysfunction in patients with diabetes mellitus (DM) FEMS. Immunol Med Microbiol. 1999;26(3-4):259-265.

11. Hinissan PK, Amy L. Adamson Glycolytic control of vacuolartype ATPase activity: A mechanism to regulate influenza viral infection. Virology. (2013);444:1-2.
12. Satman İ, Alagöl F, Ömer B, Kalaca S, Tütüncü Y, Çolak N. Türkiye Diyabet, Hipertansiyon, Obezite ve Endokrinolojik Hastalıklar Prevalans Çalışması-II. (TURDEP II) 2011.

13. Guan WJ, Ni ZY, Hu Y, Liang WH, Ou CQ, He JX, Liu L, Shan H, Lei CL, Hui DSC, Du B, Li LJ, Zeng G, Yuen KY, Chen RC, Tang CL, Wang T, Chen PY, Xiang J, Li SY, Wang JL, Liang ZJ, Peng YX, Wei L, Liu Y, Hu YH, Peng P, Wang JM, Liu JY, Chen Z, Li G, Zheng ZJ, Qiu SQ, Luo J, Ye CJ, Zhu SY, Zhong NS; China Medical Treatment Expert Group for Covid-19. Clinical characteristics of coronavirus disease 2019 in China. N Eng J Med. 2020;382:1708-1720.

14. Zhang JJ, Dong X, Cao YY, Yuan YD, Yang YB, Yan YQ, Akdis CA, Gao YD. Clinical characteristics of 140 patients infected by SARS-CoV-2 in Wuhan, China. Allergy. 2020;75(7):17301741.

15. Singh AK, Gupta R, Ghosh A, Misra A. Diabetes in COVID-19: Prevalence, pathophysiology, prognosis and practical considerations. Diabetes Metab Syndr. 2020;14(4):303-310.

16. Huttunen R, Syrjänen J. Obesity and the risk and outcome of infection. Int J Obes (Lond). 2013;37:333-340.

17. Dunn EJ, Grant PJ. Type 2 diabetes: An atherothrombotic syndrome. Curr Mol Med. 2005;5(3):323-332. 